\title{
茶のいれかたの検討
}

茶のいれかた研究会

\section{Brewing Condition of Tasty Cup of Green Tea}

\author{
Research Group of Green Tea Brewing
}

\section{1 まえがき}

茶を领むととは，わ执れ日本人の生活の中にすっか りとけこんでいる。そのためかえっていれかたに無とん 着ですばらしい茶の香味老生加しきずにいることが多 い。いうまでもなく長い歴史を持つ茶の领用であり，打 いしく飲むための指導㫪, 記事, その他，テキスト，リ ーフレット等をあげれば数かきりがない。しかし，茶は 種類が多く，同じ種類の茶でも品質はまちまちであり， 用いた茶の品質の違い，ととに好みという主観的なあの を対象としているので，その越いもあり，自加らいれ方 の条件には相当の違いがある。そ机はそれで意義があり， 当然のことのように思っているが，今回，静阔県茶業会

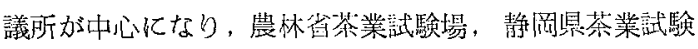
場から委員を選び，日頃わ执わ机がよく飲んでいる代表 的な茶種について，一部価格 (品位) 別他集わた茶を用 い，標準となる茶のいれかたの共同研觉を行なった。茶 をおいしくいれるには，まず，晹温，浸出温度，晹量， 茶の量などを適当に選択することが必要であり，そのほ 加地域，性別，年睮層による違いの対応む考えられる し，同し人でも䣄む場所，季䬣，体調によって違ってく るなど微妙である。このように考えると研究には不储な 点が多い。

しかし, この研究のう兮, 特にいれかたについては、 てれまで事例の少ない方法として，多くのパネルを用い た。また，おいしく领むための基迤として必要な湯温の 問題，茶の吸水量，好ましい浸出液の滛さ，そのおすな 化学成分分析，測定する等体系的な検討屯加えてある ので, 今後茶のいれかたの蔒しい研究, 調查を進めるう えにも，絶対的なあのではないにしてもそのよりどてろ になるあのが少なくないように考えられる。

\section{2 試料および実験方法}

\section{1 試料}

（1）茶 静岡県茶業会議所加暗岡市内の代表的な茶䛀 売店 6 店から購入した仕上茶 6 点を用いた。。その供試に 当たってはあらかじ裸査化よって適品を選定，茶種别 に比傚的品位のそろった 4 ～店の荼をブレンドした。 表 1 は，その茶喠および佂格（武験時）である。

表 1 陚料茶の種類と洒格

\begin{tabular}{|c|c|c|c|c|}
\hline 簽 & & 種 & 佂 & 備 \\
\hline \multirow{2}{*}{ 互 } & \multirow{2}{*}{ 形落 } & 上 & $1,000 \mathrm{FJ}$ & \multirow{2}{*}{$\begin{array}{l}\text { 価格は昭和 } 48 \text { 年 } \\
\text { 1. 月現在の } 100 \mathrm{~g}\end{array}$} \\
\hline & & 显 & $600 \sim 700 \mathrm{~W}$ & \\
\hline \multirow{2}{*}{ 煎 芽 } & 苏 & 上 & 500円 & \multirow[t]{4}{*}{ 小売値 } \\
\hline & & 蓝 & 200円 & \\
\hline 番 & & 茶 & 150円 & \\
\hline ほ & $う し$ & 茶 & 150円 & \\
\hline
\end{tabular}

（2）茶器，茶放んの容量（大きき）の選定に当たって は，茶道家の意見を䦥き，领む適量住対する体裁のよい 大きさにした。茶わんは形によって，例えば上縁が開い たものか，つぽんだ形をしているかで，いれる量仗よる 感じは違ってくるが，良質品はど少なめにいれ，茶わん の容量の1/3〜1/2量いれるのが常識である。

“きゅうす»，“どびん。の容量は，上くいれる機会 の多以人数 (茶わん数) および扔いしくいれられる，つ まりいれる条件の管理しやすい面も考虑し，玉再露，煎茶 上には 3 人分, 煎茶亚、番茶，ほうじ茶には 5 人分の適 量を浸出するととを前提として，表 2 の容量のものを選 定した。 
表 2 茶器と容量

\begin{tabular}{|c|c|c|c|c|c|c|c|c|}
\hline \multirow{2}{*}{ 茶 } & & \multirow{2}{*}{ 種 } & \multirow{2}{*}{ 茶 } & \multirow{2}{*}{ わ ん } & \multicolumn{3}{|c|}{ きうゅす・どびん } & \multirow{2}{*}{ 備 } \\
\hline & & & & & 容 & 量 & 号 & \\
\hline 玉 & & 露 & & ${ }_{40}^{\mathrm{m} l}$ & & & 1 号 & \multirow{4}{*}{$\begin{array}{l}\text { “きゅうすっ, “どびんっは五露, } \\
\text { 煎茶上については } 3 \text { 人分, 煎茶並, } \\
\text { 番茶, ほうじ茶は } 5 \text { 人分。 }\end{array}$} \\
\hline 煎 & 茶 & 上 & & 100 & & & 1.5 号 & \\
\hline 煎 & 茶 & 並 & & 150 & & & 3 号 & \\
\hline 番 & 茶・ほ & じ茶 & & 240 & & & - & \\
\hline
\end{tabular}

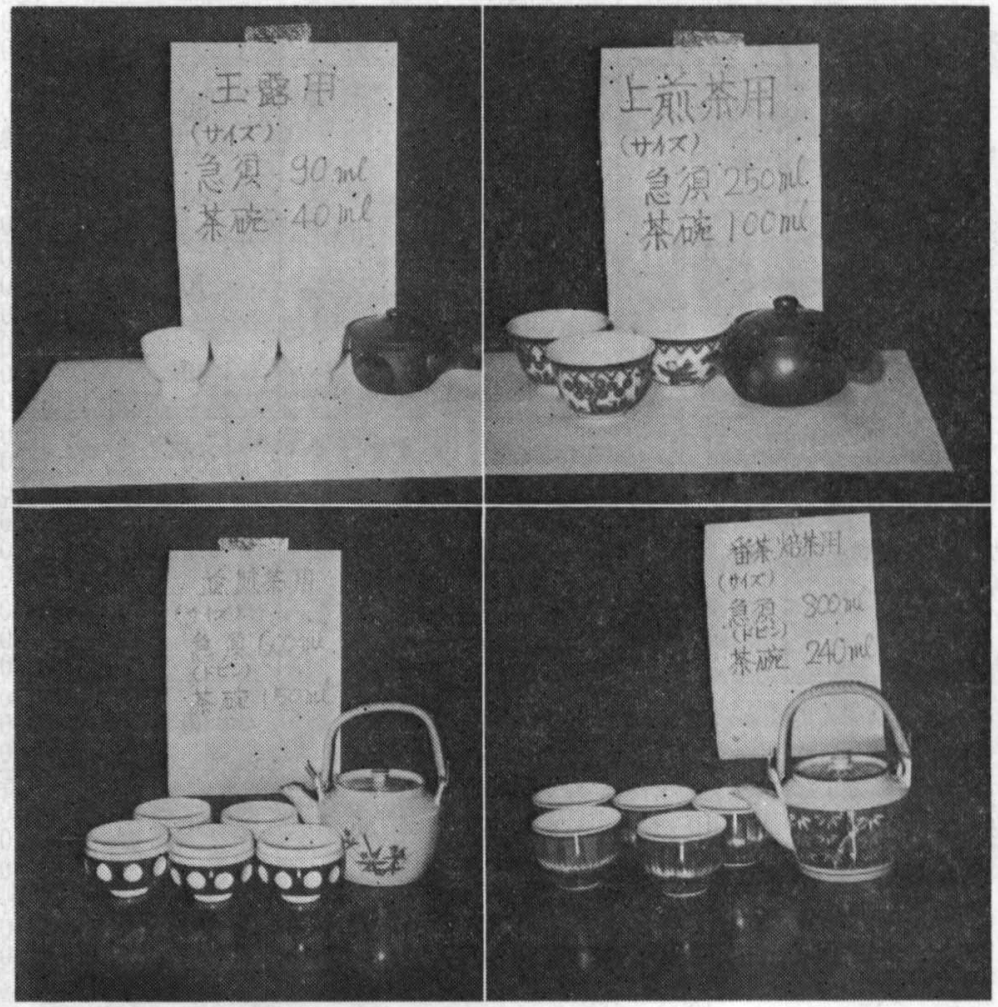

写真 1 使用した茶器

写真 1 は, 研究会で使用した“きゅうすッ, “どびんっ 茶わんである。

\section{2 試験方法}

(1) 標準浸出法（いれかたの条件）の選定

季節の違い，ことに寒暖は，飲む人の感覚および浸出 条件に相当大きな影響があるように考えられたので，夏 と冬の 2 回について武験した。夏は昭和 47 年 8 月 23 日〜 25 日の 3 日間, 冬は昭和 48 年 1 月 29 日, 30 日の 2 日間, 農林省茶業試験場審査室を会場にして行なった。

浸出条件は, 従来, テキスト,リーフレット等に記載 されているいれかたを参考にし，茶種どとに適温と考え られる温度を中心にして $10^{\circ} \mathrm{C}$ きざみで $3 \sim 4$ 段階の湯 温をえらび，さらに，それぞれの湯温について30秒きざ み， 3 段階の適当なる浸出時間を選定した。また, 官能検 查の方法は、まず, ある湯温で時間を変えた 3 点の浸出
液について，好ましい順位を 6 11名のパネルに判定さ せ, 順位合計値からその湯温での最む好ましい浸出時間 を選定した (予選)。ついで, 各湯温の最む好ましい条件 同志の比較を, 同様な方法で行ない (決選), この中で順 位合計か最小のあのをとの会の推す標準浸出法とした。

表 3 は予選時にとりあげた浸出条件で，夏は各茶種を 通じ湯温については15区，浸出時間は46区，冬は湯温 10 区，浸出時間28区について検討を行なった。

茶量の決定にはテキスト、リーフレットも参考にした が, 一部の茶種については予供漹験を行なって決定し た。湯温の調整は, 熱湯が沸騰中のあのをそのまま用い, $90^{\circ} \mathrm{C}$ 以下の湯については温度計を用いて該当温度までポ ット中でさましたものを使った。

“き由うす。，“どびんょへの注湯は，あらかじめ茶 種ごとの所要量を計測し，それぞれの“きゅうすっ，“ど 
表 3 予選時にとりあげた浸出条件（区別）

\begin{tabular}{|c|c|c|c|c|c|c|c|c|c|}
\hline \multirow{2}{*}{ 茶 } & \multirow{2}{*}{\multicolumn{2}{|c|}{ 種 }} & 茶 & 量 & \multicolumn{2}{|c|}{ 湯量 } & \multirow{2}{*}{ 湯 温 } & \multicolumn{2}{|c|}{ 浸 出 時 間 } \\
\hline & & & 夏季 & 冬季 & $3 \sim 5$ 人分 & 1 人分 & & 夏＼cjkstart季 & 冬 \\
\hline \multirow{4}{*}{ 玉 } & \multirow{4}{*}{ 簬 } & \multirow{4}{*}{ 上 } & \multirow[t]{4}{*}{$\mathrm{g}$} & \multirow[t]{4}{*}{$\mathrm{g}$} & \multirow[t]{4}{*}{$\mathrm{m} l$} & \multirow[t]{4}{*}{$\mathrm{m} l$} & $40^{\circ} \mathrm{C}$ & $\begin{array}{l}120 \text { 秒 } \\
150 \\
180 \\
\end{array}$ & 秒 \\
\hline & & & & & & & 50 & $\begin{array}{r}120 \\
150 \\
180 \\
\end{array}$ & $\begin{array}{l}120 \\
150 \\
180 \\
120\end{array}$ \\
\hline & & & & & & & 60 & $\begin{array}{r}90 \\
120 \\
150 \\
\end{array}$ & $\begin{array}{l}120 \\
150 \\
180\end{array}$ \\
\hline & & & & & & & 70 & $\begin{array}{r}90 \\
120 \\
150 \\
\end{array}$ & \\
\hline \multirow{4}{*}{ 玉 } & \multirow{4}{*}{ 露 } & \multirow{4}{*}{ 並 } & \multirow{4}{*}{10} & \multirow{4}{*}{10} & \multirow{4}{*}{60} & \multirow{4}{*}{20} & 50 & $\begin{array}{r}90 \\
120 \\
150\end{array}$ & \\
\hline & & & & & & & 60 & $\begin{array}{r}90 \\
120 \\
150 \\
\end{array}$ & $\begin{array}{r}90 \\
120 \\
150 \\
\end{array}$ \\
\hline & & & & & & & 70 & $\begin{array}{r}60 \\
90 \\
120 \\
\end{array}$ & $\begin{array}{r}60 \\
90 \\
120\end{array}$ \\
\hline & & & & & & & 80 & $\begin{array}{r}60 \\
90 \\
120 \\
\end{array}$ & \\
\hline \multirow{3}{*}{ 煎 } & \multirow{3}{*}{ 茶 } & \multirow{3}{*}{ 上 } & \multirow{3}{*}{6} & \multirow{3}{*}{6} & \multirow{3}{*}{170} & \multirow{3}{*}{ 約 57} & 60 & $\begin{array}{r}90 \\
120 \\
150 \\
\end{array}$ & $\begin{array}{r}90 \\
120 \\
150 \\
\end{array}$ \\
\hline & & & & & & & 70 & $\begin{array}{r}60 \\
90 \\
120 \\
\end{array}$ & $\begin{array}{r}60 \\
90 \\
120 \\
\end{array}$ \\
\hline & & & & & & & 80 & $\begin{array}{r}60 \\
90 \\
120 \\
\end{array}$ & $\begin{array}{r}60 \\
90 \\
120 \\
\end{array}$ \\
\hline \multirow{3}{*}{ 煎 } & \multirow{3}{*}{ 茶 } & \multirow{3}{*}{ 並 } & & & & & 80 & $\begin{array}{l}30 \\
60 \\
90 \\
\end{array}$ & \\
\hline & & & 10 & 10 & 430 & 86 & 90 . & $\begin{array}{r}\text { 即時 } \\
30 \\
60 \\
90 \\
\end{array}$ & $\begin{array}{l}30 \\
60 \\
90 \\
\end{array}$ \\
\hline & & & & & & & 熱 & $\begin{array}{r}\text { 即時 } \\
30 \\
60 \\
\end{array}$ & $\begin{array}{l}30 \\
60 \\
\end{array}$ \\
\hline & & & 10 & 10 & & & & & \\
\hline 番 & 茶，日 & 搽 & 15 & 15 & 650 & 130 & 熱 & $\begin{array}{r}\text { 即㭙 } \\
30 \\
60 \\
\end{array}$ & $\begin{array}{l}30 \\
60 \\
\end{array}$ \\
\hline & & & 20 & & & & & & \\
\hline
\end{tabular}

びんッ内面にそのレベルを記録しておき，茶を入れてか ら注晹して浸出する慣行法によった。

浸出時間はストップウォッチを用いて正確に行なっ だ。“きゅうすッ，“どびんッ加ら茶わんへのつぎ分け は，茶わんをつぎ分けやすいように並べておき，最初の 茶わんに適量の約1/3をそそぎ，順次量を增し再び逆にも どりながら各茶わんの量をならす方法を用い，“きゅう すッ，“どびんっには浸出液をはとんど残さないように つとめた。

（2）湯温（湯加げん）の測定
標準浸出法の夏および冬の浸出時の条件を考虑し， $15^{\circ} \mathrm{C}, 20^{\circ} \mathrm{C}, 25^{\circ} \mathrm{C}$ 亿調節した室内で浸出中の湯温( “き 中うすッ，“どびん、中）の低下，茶わんにつぎ分けた 液温を，その 1 分後および 2 分後まで測定するととも に，熱湯を所定の湯温までさますために要する時間を， 茶わんおよび湯さまし（玉露用）を用い， $20^{\circ} \mathrm{C} の$ 室内で 测定した。写真 2 は煎茶上の茶放んにつぎ分けた液温在 測定中のものである。な标，貨用しているポットの性能 を定量（公称 $1.9 l$ 入れ）のポット2種を用い，それに ほほ一杯熱湯をいれた場合之，約半分の1 $l$ を入れたも 


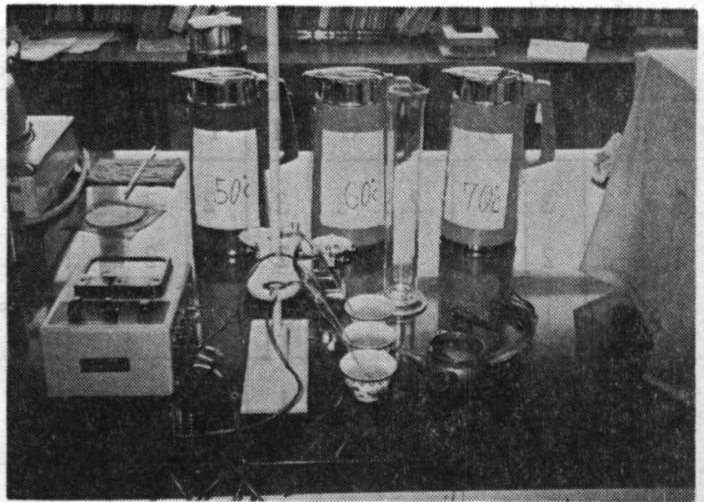

写真2 浸出液温の測定

のについて湯温の変化を調べた。

(3) 浸出液量の計測

写真 3 の実験装置を用いて本会で決めた標準浸出条件 で茶を浸出，浸出液量を計測した。

\section{（4）茶および浸出液の化学成分}

試料茶および標準浸出法によって得られた浸出液につ いて, 特に茶の味と密接な関係のあるタンニン, アミノ 酸, 可溶分を定量し, 溶出率, 漫出液中の濃度を検討し た。タンニン, 可溶分の分析は公定法, アミノ酸の分析 にはアミノ酸自動分析機（日本電子 JLC-5 AH 型）を 用いた。

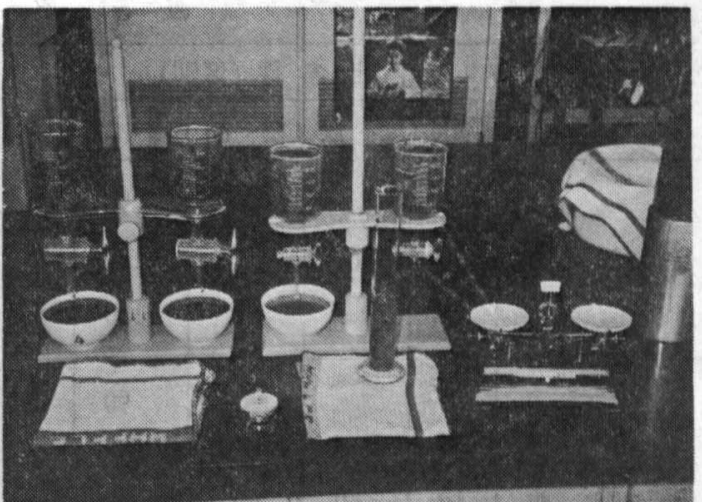

写真 3 浸出液量の計測装置

3 成績および考察

（1）標準浸出法（いれかた）の選定

ことには予選時の成績を省き，決選時の成績だけをあ げた。表 4 は夏の成績，表 5 は冬の成績である。なお， 順位合計值について, Kramer の検定法により有意に好 まれるものと好まれないあのの検定を行なった。冬の武 験には一回の決選で差が有意でなく結論が出せなかった 玉露並，煎茶上，煎茶並には多少いれかたの条件を変え た区む追加して決選を繰り返した。

表 4 夏季の浸出条件の決選

\begin{tabular}{|c|c|c|c|c|c|c|c|c|c|c|c|c|c|c|c|}
\hline \multirow{2}{*}{ 茶 } & & \multirow{2}{*}{ 種 } & \multicolumn{4}{|c|}{ 浸出条件 (区別) } & \multicolumn{3}{|c|}{ パ } & \multicolumn{2}{|c|}{ ネ } & \multicolumn{3}{|l|}{ ル* } & \multirow{2}{*}{ 計 } \\
\hline & & & 茶量 & 湯 量 & 湯 温 & $\begin{array}{ll}\text { 浸 } & \text { 出 } \\
\text { 間 }\end{array}$ & A & B & C & D & E & F & G & $\mathrm{H}$ & \\
\hline \multirow{2}{*}{ 玉 } & \multirow{2}{*}{ 露 } & \multirow{2}{*}{ 上 } & $\begin{array}{r}g \\
10\end{array}$ & $\begin{array}{l}\mathrm{ml} \\
60\end{array}$ & $\begin{array}{l}40^{\circ} \mathrm{C} \\
50 \\
60 \\
70\end{array}$ & $\begin{array}{c}180 \text { 秒 } \\
150 \\
120 \\
90\end{array}$ & $\begin{array}{l}4 \\
1 \\
2 \\
3\end{array}$ & $\begin{array}{l}1 \\
3 \\
4\end{array}$ & $\begin{array}{l}3 \\
1 \\
2 \\
4\end{array}$ & $\begin{array}{l}2 \\
1 \\
3 \\
4\end{array}$ & $\begin{array}{l}1 \\
2 \\
3 \\
4\end{array}$ & $\begin{array}{l}1 \\
2.5 \\
2.5 \\
4\end{array}$ & & & $\begin{array}{c}13 \\
8.5^{*} \\
15.5 \\
23^{*}\end{array}$ \\
\hline & & & $\begin{array}{l}10 \\
6\end{array}$ & 60 & $\begin{array}{l}50 \\
40 \\
60 \\
50\end{array}$ & $\begin{array}{l}150 \\
180 \\
120 \\
150\end{array}$ & $\begin{array}{l}2 \\
1 \\
4 \\
3\end{array}$ & $\begin{array}{l}1 \\
4 \\
2 \\
3\end{array}$ & $\begin{array}{l}1 \\
2 \\
4 \\
3\end{array}$ & $\begin{array}{l}1 \\
4 \\
2 \\
3\end{array}$ & $\begin{array}{l}3 \\
4 \\
1 \\
2\end{array}$ & $\begin{array}{l}1 \\
4 \\
2 \\
3\end{array}$ & $\begin{array}{l}1 \\
3 \\
4 \\
2\end{array}$ & & $\begin{array}{l}10 \\
22^{*} \\
19 \\
19\end{array}$ \\
\hline 玉 & 露 & 並 & 10 & 60 & $\begin{array}{l}50 \\
60 \\
70\end{array}$ & $\begin{array}{r}120 \\
120 \\
90\end{array}$ & $\begin{array}{l}1 \\
2.5 \\
2.5\end{array}$ & $\begin{array}{l}1 \\
2 \\
3\end{array}$ & $\begin{array}{l}2 \\
1 \\
3\end{array}$ & $\begin{array}{l}1 \\
2 \\
3\end{array}$ & $\begin{array}{l}2 \\
1 \\
3\end{array}$ & $\begin{array}{l}3 \\
1 \\
2\end{array}$ & $\begin{array}{l}2 \\
1 \\
3\end{array}$ & $\begin{array}{l}1 \\
2.5 \\
2.5\end{array}$ & $\begin{array}{l}13 \\
13 \\
22^{*}\end{array}$ \\
\hline 煎 & 茶 & 上 & 6 & 170 & $\begin{array}{l}60 \\
70 \\
80\end{array}$ & $\begin{array}{r}120 \\
90 \\
90\end{array}$ & $\begin{array}{l}1 \\
2 \\
3\end{array}$ & $\begin{array}{l}2 \\
1 \\
3\end{array}$ & $\begin{array}{l}1 \\
2 \\
3\end{array}$ & $\begin{array}{l}1 \\
2 \\
3\end{array}$ & $\begin{array}{l}2 \\
1 \\
3\end{array}$ & $\begin{array}{l}3 \\
1 \\
2\end{array}$ & $\begin{array}{l}1 \\
2 \\
3\end{array}$ & $\begin{array}{l}1 \\
2 \\
3\end{array}$ & $\begin{array}{l}12 \\
13 \\
23^{*}\end{array}$ \\
\hline 煎 & 茶 & 並 & 10 & 430 & $\begin{array}{c}80 \\
90 \\
\text { 熱湯 }\end{array}$ & $\begin{array}{l}90 \\
60 \\
60\end{array}$ & $\begin{array}{l}2 \\
1 \\
3\end{array}$ & $\begin{array}{l}2 \\
1 \\
3\end{array}$ & $\begin{array}{l}2 \\
1 \\
3\end{array}$ & $\begin{array}{l}2 \\
1 \\
3\end{array}$ & $\begin{array}{l}2 \\
1 \\
3\end{array}$ & $\begin{array}{l}1 \\
2 \\
3\end{array}$ & $\begin{array}{l}2 \\
1 \\
3\end{array}$ & & $\begin{array}{c}13 \\
8^{*} \\
21^{*}\end{array}$ \\
\hline 番茶, & ほ & & 15 & 650 & 熱湯 & $\begin{array}{r}\text { 即時 } \\
30\end{array}$ & $\begin{array}{l}2 \\
1\end{array}$ & $\begin{array}{l}2 \\
1\end{array}$ & $\begin{array}{l}2 \\
1\end{array}$ & $\begin{array}{l}2 \\
1\end{array}$ & $\begin{array}{l}2 \\
1\end{array}$ & $\begin{array}{l}2 \\
1\end{array}$ & $\begin{array}{l}2 \\
1\end{array}$ & & $\begin{array}{r}16^{*} \\
8^{*}\end{array}$ \\
\hline
\end{tabular}

注：* Kramer の順位合計の検定から有意にうまいあしくはまずいと判定されたもの。 
表 5 冬抙の浸出条件の決選

\begin{tabular}{|c|c|c|c|c|c|c|c|c|c|c|c|c|c|c|c|c|c|c|}
\hline \multirow{2}{*}{ 茶 } & & \multirow{2}{*}{ 種 } & \multicolumn{4}{|c|}{ 浸 出 条 件 (区別) } & \multicolumn{5}{|c|}{ パ } & \multicolumn{2}{|l|}{ ネ } & \multicolumn{4}{|l|}{ ル } & \multirow{2}{*}{ 計 } \\
\hline & & & 茶量 & 晹 量 & 湯 温 & $\begin{array}{l}\text { 浸 出間 } \\
\text { 時 }\end{array}$ & A & B & $\mathrm{C}$ & $\mathrm{D}$ & E & F & $\mathrm{G}$ & $\mathrm{H}$ & I & $\mathrm{J}$ & $\mathrm{K}$ & \\
\hline \multirow{3}{*}{ 玉 } & \multirow{3}{*}{ 露 } & \multirow{3}{*}{ 上 } & \multirow{3}{*}{10} & \multirow{3}{*}{60} & \multirow[t]{2}{*}{$60^{\circ} \mathrm{C}$} & $90^{\text {秒 }}$ & 1.5 & 1.5 & 2 & 3 & 2 & 2.5 & 3 & 3 & 2 & 3 & & 23.5 \\
\hline & & & & & & 120 & 1.5 & 3 & 3 & 2 & 3 & 1 & 2 & 2 & 3 & 2 & & 22.5 \\
\hline & & & & & 50 & 150 & 3 & 1.5 & 1 & 1 & 1 & 2.5 & 1 & 1 & 1 & 1 & & $14^{*}$ \\
\hline \multirow{4}{*}{ 玉 } & \multirow{4}{*}{ 露 } & \multirow{4}{*}{ 並 } & \multirow{4}{*}{10} & \multirow{4}{*}{60} & \multirow{4}{*}{60} & 90 & 1 & 2 & 2 & 2 & 2 & & 1 & 1 & 2 & 2 & & 15 \\
\hline & & & & & & 120 & 2 & 1 & 1 & 1 & 1 & & 2 & 2 & 1 & 1 & & 12 \\
\hline & & & & & & 90 & 1 & 2 & 2 & 1 & 2 & & 2 & 2 & 2 & 2 & & 16 \\
\hline & & & & & & 120 & 2 & 1 & 1 & 2 & 1 & & 1 & 1 & 1 & 1 & & 11 \\
\hline \multirow{5}{*}{ 煎 } & \multirow{5}{*}{ 茶 } & \multirow{5}{*}{ 上 } & \multirow{5}{*}{6} & \multirow{5}{*}{170} & 80 & 90 & 2 & 2 & 2 & 2 & 1.5 & & 1 & 1 & 2 & 2 & & 15 \\
\hline & & & & & 70 & 120 & 1 & 1 & 1 & 1 & 1.5 & & 2 & 2 & 1 & 1 & & 12 \\
\hline & & & & & 80 & 90 & 3 & 1 & 3 & 3 & 3 & 2 & 2 & 3 & 3 & 2 & & 25 \\
\hline & & & & & 70 & 120 & 1 & 2 & 1 & 1 & 1 & 1 & 1 & 1 & 2 & 1 & & $12^{*}$ \\
\hline & & & & & 60 & 150 & 2 & 3 & 2 & 2 & 2 & 3 & 3 & 2 & 1 & 3 & & 23 \\
\hline \multirow{5}{*}{ 煎 } & \multirow{5}{*}{ 茶 } & \multirow{5}{*}{ 並 } & & (1) & 熱湯 & 30 & 1 & 1 & 2 & 1 & 1 & 1 & 2 & 2 & 1 & 2 & & 14 \\
\hline & & & & & 90 & 60 & 2 & 2 & 1 & 2 & 2 & 2 & 1 & 1 & 2 & 1 & & 16 \\
\hline & & & 10 & 430 & 熱湯 & 30 & 2 & 1 & 2 & 2 & 3 & 2 & 3 & 1.5 & 3 & 3 & & 22.5 \\
\hline & & & & (2) & 90 & 60 & 1 & 2 & 1 & 1 & 1 & 1 & 1 & 1.5 & 2 & 1 & & $12.5^{*}$ \\
\hline & & & & & 80 & 90 & 3 & 3 & 3 & 3 & 2 & 3 & 2 & 3 & 1 & 2 & & 25 \\
\hline & & & 15 & & & 即時 & 2 & 2 & 2 & 2 & 3 & 1 & 3 & 3 & 3 & 1 & & 22 \\
\hline 番 & & 茶 & & 650 & 熱湯 & 30 & 1 & 1 & 1 & 1 & 1 & 2 & 1 & 1 & 1 & 2 & & $12^{*}$ \\
\hline & & & 10 & & & 60 & 3 & 3 & 3 & 3 & 2 & 3 & 2 & 2 & 2 & 3 & & $26^{*}$ \\
\hline & & & 15 & & & 即時 & 2 & 2 & 2 & 3 & 3 & 3 & 2 & 3 & 3 & 1 & 2 & 26 \\
\hline ほ & じ & 茶 & & 650 & 熱湯 & 30 & 1 & 1 & 1 & 1 & 1 & 1 & 1 & 1.5 & 1 & 3 & 3 & $15.5^{*}$ \\
\hline & & & 10 & & & 60 & 3 & 3 & 3 & 2 & 2 & 2 & 3 & 1.5 & 2 & 2 & 1 & 24.5 \\
\hline
\end{tabular}

注：* Kramer の顀位合計の検定から有意にうまいあしくはまずいと判定されたもの。

番茶，ほうじ茶については決選時に茶量を $10 \mathrm{~g}$ 亿減ら し，浸出にやや時間を加けた場合のものを加えた効果も 検討した。

表6は夏と冬に成績の上加だいれ加たっの条件を まとめたあのである。夏之冬の丙露並, 夏の煎茶上の湯 温, 浸出時間に二つの条件のの甘てあるのは，この二つ の条件の間の差が決選を繰り返してあ有意でなかったた めである。試験をする前には，夏之冬の間にはかなり違 いの生ずるととを考えていたが，結果は予想に反し，普
通室内で茶をいれて飲むかぎりでは大差ないととがわか った。

そてで, 夏, 冬の最適浸出条件の違うあのについて予 選, 決選時の順位合計值の多少を参考にして, 最良の条 件を一つにしばり，表 7 亿示す茶種別標準浸出法を決定 した。

（2）茶浸出中の湯温之浸出液温

標準漫出法を用いて浸出（“きゅうす»，“どびんょ) 中の湯温と，茶われに移し飲むときにわれわれが感ずる 
表 6 夏・冬季の好浸出条件

\begin{tabular}{|c|c|c|c|c|c|}
\hline \multirow{2}{*}{ 茶 種 } & \multirow{2}{*}{ 季別 } & \multicolumn{2}{|c|}{ 浸 } & \multicolumn{2}{|c|}{ 条 件 } \\
\hline & & 茶 量 & 湯 量 & 湯 温 & 浸出時間 \\
\hline \multirow{2}{*}{ 玉露上 } & 夏 & $10^{\mathrm{g}}$ & ${ }_{60}^{\mathrm{m} l}$ & ${ }_{50}^{\circ} \mathrm{C}$ & $150^{\text {秒 }}$ \\
\hline & 冬 & 10 & 60 & 50 & 150 \\
\hline \multirow{2}{*}{ 玉露 並 } & 夏 & 10 & 60 & 50 & 120 \\
\hline & 옷 & 10 & 60 & 60 & 120 \\
\hline \multirow{2}{*}{ 煎茶上 } & 夏 & 6 & 170 & 60 & 120 \\
\hline & 冬 & 6 & 170 & 70 & 120 \\
\hline \multirow{2}{*}{ 煎茶並 } & 夏 & 10 & 430 & 90 & 60 \\
\hline & 冬 & 10 & 430 & 90 & 60 \\
\hline \multirow{2}{*}{ 番 茶 } & 夏 & 15 & 650 & 熱晹 & 30 \\
\hline & 冬 & 15 & 650 & 熱晹 & 30 \\
\hline \multirow{2}{*}{ ほうじ茶 } & 夏 & 15 & 650 & 熱湯 & 30 \\
\hline & 冬 & 15 & 650 & 熱湯 & 30 \\
\hline
\end{tabular}

表 7 標集浸出法

\begin{tabular}{|c|c|c|c|c|c|c|}
\hline \multirow{2}{*}{ 茶 } & & \multirow{2}{*}{ 種 } & \multicolumn{2}{|c|}{ 浸 } & 条 & 件 \\
\hline & & & 茶 量 & 湯 眰 & 㪚 温 & 浸出時間 \\
\hline 玉 & 露 & 上 & ${ }_{10} \mathrm{~g}$ & ${ }_{60}^{\mathrm{m}}$ & ${ }_{50}^{\circ} \mathrm{C}$ & 150 \\
\hline 玉 & 露 & 並 & 10 & 60 & 60 & 120 \\
\hline 煎 & 茶 & 上 & 6 & 170 & 70 & 120 \\
\hline 槊 & 茶 & 並 & 10 & 430 & 90 & 60 \\
\hline 番 & & 茶 & 15 & 650 & 熱湯 & 30 \\
\hline$ほ$ & $う し$ & 茶 & 15 & 650 & 熱晹 & 30 \\
\hline
\end{tabular}

湯温について検討したもので, 図 1 は室温 $15^{\circ} \mathrm{C}$, 図 2 は 室温 $20^{\circ} \mathrm{C}$, 図 3 は室温 $25^{\circ} \mathrm{C}$ 下の経過である。いずれす 3 回測定した平均値を示した。困中に破線で示してある 部分は，つぎ分けに要する時間で，“き由うすっ，“ど びん。の形, 構造, 大きさによって異なり, 平均水切り に 45 秒内外加るが，ここにはその時間を 60 秒みてあ る。室温の高低は, 茶浸出中の晹温恬もち万ん, 茶わ九 に移した後の液温にあ影響する。 $15^{\circ} \mathrm{C}$ の埸合の玉露上の 液温はやや低温汇過ぎ， $25^{\circ} \mathrm{C}$ の窒内でいれた番茶，ほう じ茶，煎茶並の浸出直後の液温については高温に過ぎる という批判もあった。

\section{(3) 晹冷ましに要する時間}

煎茶並の浸出に適当な $90^{\circ} \mathrm{C}$ の湯は，一度“どびん。

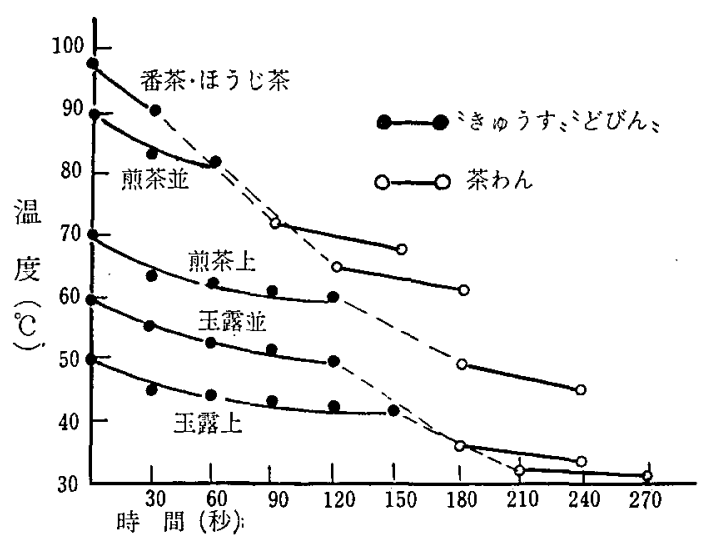

図 1 茶種別浸出湯温と浸出液温（室温 $15^{\circ} \mathrm{C}$ )

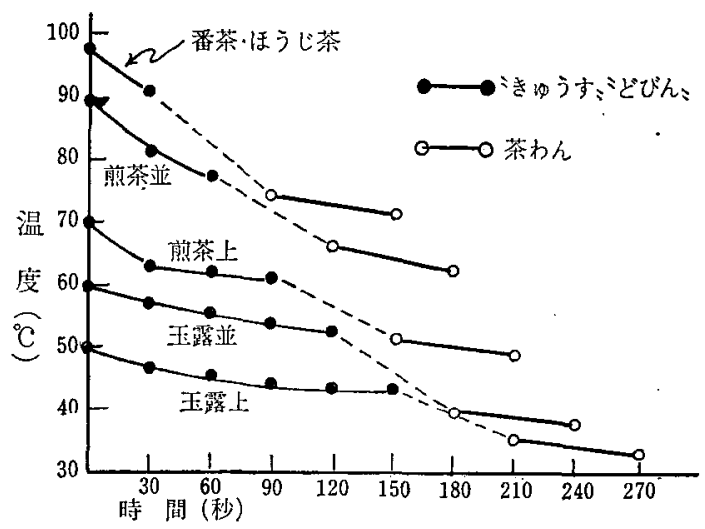

図 2 茶種別浸出晹温と浸出液温 $\left(\right.$ 室温 $20^{\circ} \mathrm{C}$ )

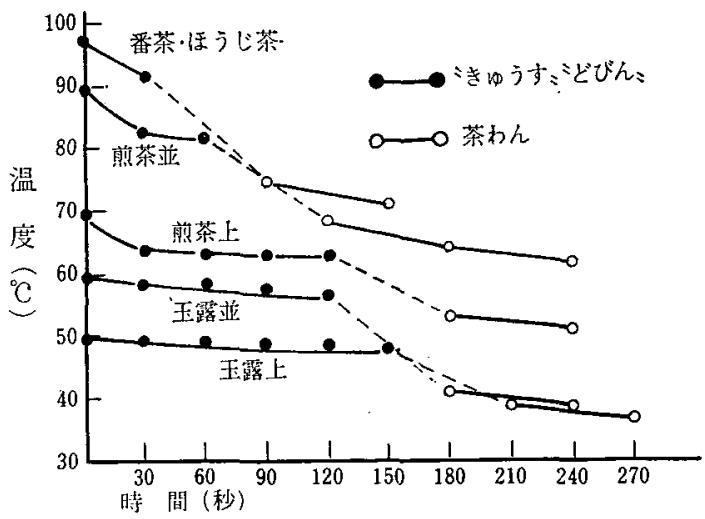

図 3 茶種別浸出晹温と浸出液温）室温 $25^{\circ} \mathrm{C}$ )

に熱晹をいれれば $90^{\circ} \mathrm{C}$ 内外になり，それをそのまま茶 をいれた“どびんっに移せばよい。したがって，ここに は玉露上, 玉露並, 煎茶上を抢いしくいれるために必要 な, $50^{\circ} \mathrm{C}, 60^{\circ} \mathrm{C}, 70^{\circ} \mathrm{C}$ の湯温にするために要する湯冷 ましの時間を 3 回反復測定した。

図4 は玉露用茶器に普通付いている“湯冷ましっの浅 底 (平型), 深底 (变形) の 2 種いず札も容量約 $60 \mathrm{~m} l$ 入 


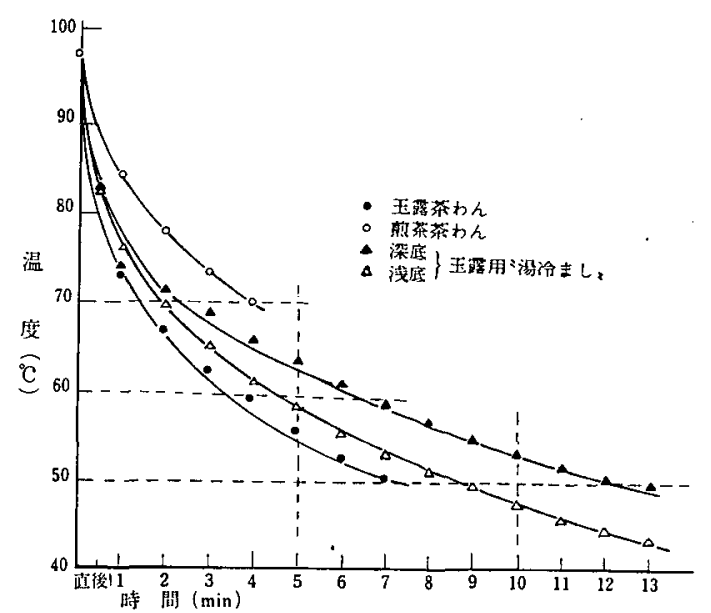

図 4 晹冷まし用具別の湯温変化

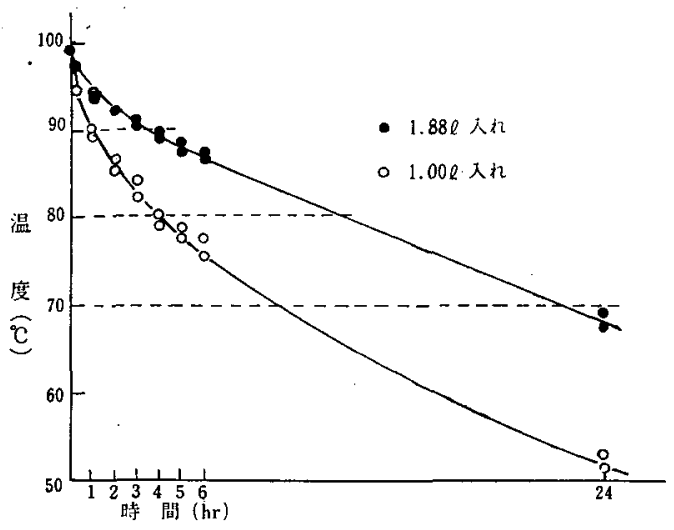

図 5 ポットの注湯量と湯温の変化

れと，研究会が選定した既述の玉露茶わんに，その容量 の約半分の $20 \mathrm{ml}$ の熱湯をいれて行なう湯ざまし，およ び槊茶は茶方ん注約 $60 \mathrm{~m} l$ の熱湯をいれてさます場合の 経時的変化を示したものである。図4でわかるように， 湯冷ましに要する時間は茶わんを使ったもののほうが玉 露専用の“晹ざまし』を用いて行なうものよりも早かっ た。なお，ての測定には茶器はいずれす $20^{\circ} \mathrm{C}$ の湯で洗 浄したものを用いた。乙の結果は試験で用いた茶以外の あのをいれる場合にも，その茶質化合った湯温にするた 內の目安にあなるように思加れる。

図 5 はポットに熱湯をいれた場合の湯温の経過であ る。晹量の少ない場合はその低下は早かった。

(4) 浸出液量

表 8 は室温 $20^{\circ} \mathrm{C}$ 下に 3 回浸出した平均値である。莱 量に対し湯量が多い場合は浸出液量の割合は多い。しか し，晹量の多い場合は茶そのものの吸水量は多くなる。 表では煎茶並が茶の単位重量当たりでみると吸水量が最 も多い。乙の吸水量には湯温，漫出時間の影㗽があり， 晹温の低いあの, 浸出時間の短いあのも当然のととでは
表 8 浸出量亡茶の吸水量

\begin{tabular}{|c|c|c|c|c|c|c|c|}
\hline 茶 & 種 & 茶量 & 湯量 & \multicolumn{2}{|c|}{ 浸 出 量 } & $\mid \begin{array}{ll}\text { 茶 } & 9 \\
\text { 吸水量 }\end{array}$ & 财水量/ \\
\hline 玉 露 & 上 & $10^{g}$ & $\begin{array}{l}\mathrm{m} l \\
60\end{array}$ & $\begin{array}{c}\mathrm{m} l \\
36^{2}\end{array}$ & $60^{96}$ & $\mathrm{~m}_{24}^{\mathrm{m} l}$ & $2.4^{\mathrm{ml}}$ \\
\hline 玉露 & 业 & 10 & 60 & 37.5 & 62.5 & 22.5 & 2.3 \\
\hline 煎茶 & 上 & 6 & 170 & 151 & 88.8 & 19 & 3.2 \\
\hline 煎茶 & 並 & 10 & 430 & 394 & 91.6 & 36 & 3.6 \\
\hline 番 & 茶 & 15 & 650 & 607 & 93.4 & 43 & 2.9 \\
\hline ほうじ & & 15 & 650 & 607 & 93.4 & 43 & 2.9 \\
\hline
\end{tabular}

表 9 茶抢よび浸出液のタンニン

\begin{tabular}{|c|c|c|c|c|c|c|}
\hline 茶 & & 種 & 茶 & 浸出液中 & 浸出液/苓 & $\begin{array}{l}\text { 浸出液 } \\
\text { 中濃度 }\end{array}$ \\
\hline 玉 & 露 & 上 & $11.4 \%$ & $0.99^{\%}$ & $8.6^{90}$ & $0.16^{90}$ \\
\hline 玉 & 露 & 並 & 12.28 & 0.99 & 8.1 & 0.16 \\
\hline 煎 & 茶 & 上 & 14.32 & 2.74 & 19.1 & 0.16 \\
\hline 煎 & 茶 & 並 & 13.54 & 2.81 & 20.8 & 0.07 \\
\hline 番 & & 茶 & 11.49 & 1.72 & 15.0 & 0.03 \\
\hline ほ & うじ & 茶 & 9.92 & 1.79 & 18.0 & 0.03 \\
\hline
\end{tabular}

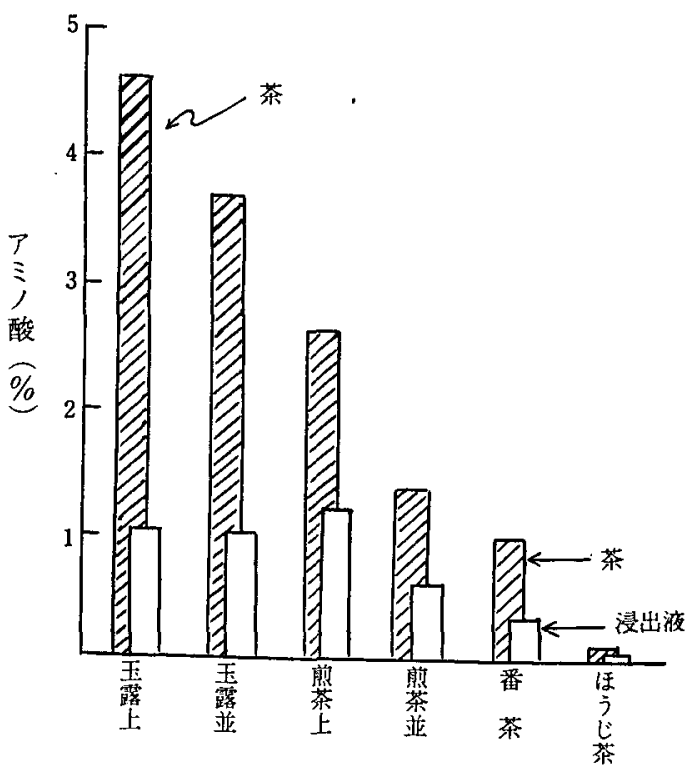

図 6 茶と漫出液中のタンニン

あるが茶の吸水量は少なかった。

(5) 茶および浸出液の化学成分

1) タン ン

表 9, 図6はタンニンの分析成績である。茶タンニン の分析の場合は, エステル型カテキンは遊離型カテキン に比較すると浸出されにくいので，浸出液中のタンニン 
表 10 䒩拈よび浸出液のアミノ酸 (1)（mg\%）

\begin{tabular}{|c|c|c|c|c|c|c|c|c|c|c|c|c|}
\hline 茶 種 & & & 节 & 苶 & & & & 浸 & 占 & 出 & 液 & \\
\hline アミノ酸 & 玉露上 & 玉露並 & 煎茶上 & 煎茶亚 & 番 茶 & ほうじ & 玉露上 & 玉露並 & 煎茶上 & 煎茶並 & 番茶 & ほうじ \\
\hline 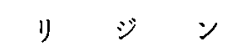 & 39.1 & 32.7 & 28.7 & 14.0 & 10.1 & 1.4 & 8.6 & 9.2 & 12.1 & 5.4 & 2.7 & 0.6 \\
\hline ヒスチジン & 28.2 & 22.1 & 10.3 & 7.6 & 6.6 & 0.9 & 5.6 & 3.1 & 5.5 & 3.4 & 1.9 & 0.5 \\
\hline $\boldsymbol{T} Y \epsilon=\boldsymbol{T}$ & 9.3 & 9.1 & 9.2 & 7.0 & 7.1 & 9.4 & 1.6 & 1.7 & 3.0 & 2.0 & 1.4 & 2.8 \\
\hline 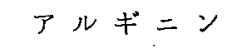 & 497.5 & 329.6 & 198.1 & 64.2 & 38.9 & 14.6 & 77.7 & 48.9 & 78.0 & 21.3 & 12.0 & 3.1 \\
\hline アスパラギン酸 & 432.5 & 333.0 & 245.8 & 172.9 & 124.9 & 27.2 & 128.6 & 103.9 & 123.7 & 87.1 & 49.3 & 10.6 \\
\hline ス $v オ=ン$ & 128.8 & 98.3 & 48.0 & 29.1 & 23.0 & 3.2 & 33.2 & 29.4 & 37.5 & 13.9 & 7.2 & 0.9 \\
\hline リ & 352.8 & 277.9 & 202.0 & 114.3 & 82.4 & 10.3 & 97.1 & 85.3 & 116.1 & 53.5 & 26.6 & 3.7 \\
\hline $\bar{\tau} \boldsymbol{\gamma}=\nu$ & 2466.1 & 2007.7 & 1496.6 & 652.5 & 416.7 & 21.7 & 621.7 & 535.7 & 593.2 & 264.0 & 141.3 & 6.4 \\
\hline グルタミン酸 & 449.4 & 383.5 & 217.4 & 214.3 & 184.5 & 16.7 & 112.2 & 107.2 & 129.8 & 99.1 & 57.4 & 16.2 \\
\hline グリ シ ン & 4.8 & 4.3 & 5.0 & 3.8 & 3.0 & 1.0 & 1.9 & 2.2 & 1.5 & 1.1 & 0.7 & 0.5 \\
\hline$\gamma \bar{\gamma}=\nu$ & 54.8 & 40.8 & 28.3 & 24.7 & 20.2 & 3.9 & 15.0 & 13.4 & 12.5 & 11.4 & 6.2 & 1.5 \\
\hline バ リ ン & 25.2 & 21.5 & 18.9 & 14.2 & 8.2 & 1.1 & 7.0 & 6.6 & 11.5 & 6.3 & 2.8 & 0.5 \\
\hline イソロイシン & 36.1 & 28.6 & 14.4 & 11.7 & 7.5 & 0.9 & 9.9 & 7.6 & 9.7 & 5.5 & 2.9 & 0.3 \\
\hline ロイシン & 32.6 & 26.6 & 15.5 & 10.7 & 3.2 & 0.6 & 8.7 & 6.5 & 9.6 & 4.4 & 2.0 & 0.2 \\
\hline チ口 シ ン & 29.6 & 30.9 & 25.7 & 16.3 & 8.5 & 1.1 & 7.4 & 5.9 & 12.1 & 6.2 & 2.6 & 0.2 \\
\hline フェニル & 37.7 & 41.2 & 31.4 & 24.8 & 14.2 & 1.1 & 7.1 & 8.0 & 15.4 & 8.6 & 3.9 & 0.3 \\
\hline 合 & 4624.5 & 3687.8 & 2595.3 & 1382.1 & 958.6 & 115.1 & 1143.3 & 974.6 & 1171.3 & 593.2 & 320.9 & 48.3 \\
\hline
\end{tabular}

組成は，茶のタンニン組成よりも遊離型の含有比率が高 くなる。したがって、タンニンの公定法分析では遊離型 カテキンのほうが発色しにくいので, 浸出液中のタンニ ン量は実際よりあ低い值を示しているむのと考えられ

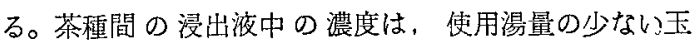
露, 煎茶上のほうが高かった。

\section{2) $了 ミ /$ 酸}

表10, 図 7 はアミノ酸の分析成績である。茶ではその 合計でみるとよくわかるように玉露, 煎茶上に多く，番 茶特にほうじ茶に少ない。ところが，浸出液中に移って くるアミノ酸の割合は、表11のように煎茶、ほうじ茶が 高く量的に最あ多いアミノ酸であるテアニンについてあ ほほ同じような傾向が認められた。浸出液中の濃度で

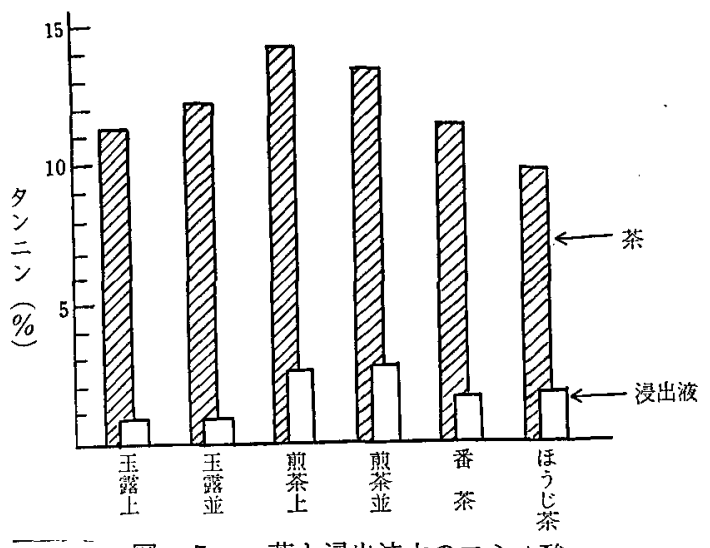

表 11 茶および浸出液のアミノ酸 (2)

\begin{tabular}{|c|c|c|c|c|c|c|c|c|c|c|}
\hline \multirow{2}{*}{ 茶 } & & \multirow{2}{*}{ 種 } & \multicolumn{2}{|c|}{ 茶 } & \multicolumn{2}{|c|}{ 浸出液/浸出量 } & \multicolumn{2}{|c|}{ 浸出液/茶浸出率 } & \multicolumn{2}{|c|}{ 浸出液中濃度 } \\
\hline & & & アミノ酸 & テアニン & アミノ酸 & テアニン & アミノ酸 & テアニン & 厂ミノ酸 & テアニン \\
\hline 玉 & 露 & 上 & $4.62 \%$ & $2.47 \%$ & $1.14 \%$ & $0.62 \%$ & $24.72^{\circ}$ & $25.21 \%$ & $0.19 \%$ & $0.10 \%$ \\
\hline 玉 & 露 & 並 & 3.69 & 2.01 & 0.97 & 0.54 & 26.42 & 26.68 & 0.16 & $0: 09$ \\
\hline 煎 & 茶 & 上 & 2.60 & 1.50 & 1.17 & 0.57 & 45.13 & 39.64 & 0.04 & 0.02 \\
\hline 煎 & 茶 & 並 & 1.38 & 0.65 & 0.59 & 0.26 & 42.90 & 40.45 & 0.013 & 0.006 \\
\hline 番 & & 茶 & 0.96 & 0.42 & 0.32 & 0.14 & 33.45 & 33.89 & 0.005 & 0.003 \\
\hline ほ & $う し ゙$ & 茶 & 0.11 & 0.02 & 0.05 & 0.01 & 41.85 & 29.52 & 0.00 & 0.00 \\
\hline
\end{tabular}


は，玉露，热策上の濃度は高く番箖，ほうじ茶の濃度は 著しく低かった。

3) 可浴 分

表12, 図 8 が可溶分の分析成績である。香茶, ほうじ 茶の可溶分瑹ではやや少ないが, 浸出量および浸出す る割合は玉露よりも高い。玉露は晹温を下げ茶に対する 晹量を少なくすることで，浸出液の濃度を高めているた め，その浸出がかなり抑制されているものと思われる。

表 12 茶わよび浸出液の可溶分

\begin{tabular}{|c|c|c|c|c|}
\hline 蓧㮔 & 茶 & $\begin{array}{c}\text { 漫出液/ } \\
\text { 漫出量 }\end{array}$ & $\begin{array}{l}\text { 浸出液/ } \\
\text { 茶浸出率 }\end{array}$ & $\begin{array}{l}\text { 浸出液 } \\
\text { 中濃度 }\end{array}$ \\
\hline 玉露上 & $40.56^{8}$ & $7.66^{90}$ & $18.9^{96}$ & $1.28^{9}$ \\
\hline 玉露並 & 40.56 & 6.72 & 16.6 & 1.12 \\
\hline 煎茶上 & 41.29 & 11.90 & 28.8 & 0.70 \\
\hline 䔮茶並 & 39.04 & $12.30^{\circ}$ & 31.5 & 0.29 \\
\hline 番 茶 & 33.58 & 9.19 & 27.4 & 0.14 \\
\hline ほうじ茶 & 34.52 & 8.23 & 23.8 & 0.13 \\
\hline
\end{tabular}

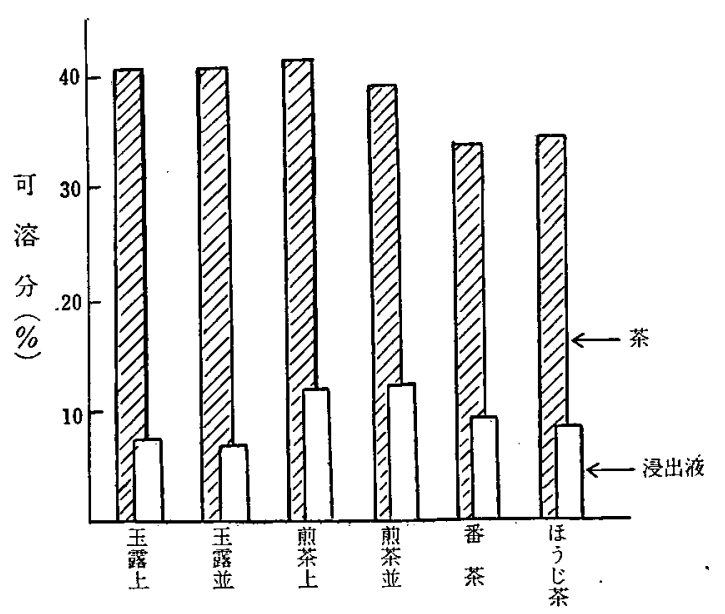

図 8 茶と浸出液中の可溶分

$$
4 \text { 要 約 }
$$

1）茶のおいしいいれかたについて, 玉露, 煎茶, 番 茶，ほうじ茶の代表的な市貾品を用い，夏上冬の 2 回， 茶量, 晹量, 浸出時間を変えてだしたものを 7 ～11人の パネルに飲ませ順位法で評価し、標準浸出法を決定し た。その結果, 高級茶ほよ゙，晹量を少なくし，晹温を低 くしてゆっくり浸出したほうがうまく，下級茶は晹量を 多くし，熱湯もしくは高温の晹で短時間に浸出したもの がうまかった。

2）標準浸出法を用いるに当って必要な，晹温の調 整, 得られる液量, 液温等を討测した結果, 上級茶では 用いる湯量が少ないためその 20〜40\%が茶に吸収され浸
流液量が少なくなるが，下級茶では晹量が多いため $10 \%$ 程度しか吸収されないので用いる湯量と浸出液量があま り変わらないとと, 室温 $15^{\circ} \mathrm{C}$ では上級茶の飲用温度が 低くなり過ぎ， $25^{\circ} \mathrm{C}$ では下級茶の饮用温度が高すぎる 場合があった。

3）この研究に供試した茶と本会で決めた標準浸出法 で得た浸出液について，タンニン，アミノ酸，可浴分を 定量した結果，高級茶の琶準浸出液は濃度が高く，低洫 浸出によってタンニンの摔出がおさえられるためタンニ ンに対するアミノ酸の比率が高いとと，下級茶の栖染漫 出液は溽度が低く，アミノ酸が少ないことが認められ た。

茶のいれかた研究会メンバー

農林省茶業武験場 桑原穆夫・中!!致之

静岡県茶業試験場 大石貞夫・森園市二・本杉昭二 静凧県茶商工業協同組合連合会 加藤忠七郎 静同県茶業会䛨所 藤江太兵衛

終わりにのぞみ，乙の研究の推進に多大のご援助をい ただいた静岡目茶業会議所会頭秋野三千雄氏，同会事務 局長俥山正雄氏，研究にご協力をいただいた農林省茶業 武験場斉藤 弘氏，天野いね氏，静成県茶業試験場佐藤

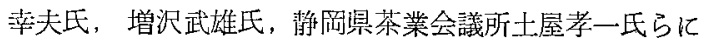
負うとてろむ大きく感謝の意を表します。

\section{5 文献}

1) 加藤儀一即：茶効聖典, 51〜63 (1941).

2) 朝日新聞社学芸部編：お茶のす心゙て，160１70 (1958).

3）梄林忠男：槊茶の世界, 203〜229 (1972).

4) 小川八重子：槊茶入門, 256～259 (1973).

5) 桑原穆夫: 茶, $18(5), 38 \sim 42$ (1965).

9）壏月弥栄子, 松永恵王：マイライフ，38４2 (1967).

7) 堤 好石：主婦上生活, 5, 153 160 (1971).

8) 水野正夫：主婦の友，2，71～78 (1972).

9）小川後楽, 干 澄子：家庭画報, 11, 17〜 40 (1972).

10）小川八重子, 植田道子 : 婦人俱楽部, 11, 171 174 (1972).

11）化学研究室: 茶試研報, No. 6, 169 (1970). (June 25, 1973) 